\title{
The Emergence and Development of Indigenous Tea Plantations in West Java, 1875-1941
}

\author{
*ALWI ALATAS \\ WAN SUHANA WAN SULONG \\ Department of History and Civilization, Kuliyyah of Islamic Revealed Knowledge and Human \\ Sciences, International Islamic University Malaysia, 53100 Gombak, Malaysia \\ *Corresponding author: alwialatas@iium.edu.my
}

Published online: 20 October 2020

To cite this article: Alwi Alatas and Wan Suhana Wan Sulong. 2020. The emergence and development of indigenous tea plantations in West Java, 1875-1941. KEMANUSIAAN the Asian Journal of Humanities 27(2): 39-58. https://doi.org/10.21315/kajh2020.27.2.3

To link to this article: https://doi.org/10.21315/kajh2020.27.2.3

\begin{abstract}
Indigenous people in Java in the colonial era were often portrayed as a communal society, socially oriented and not in line with the market economy dominated by the Dutch administration. However, this over-simplifies the picture, especially with regard to the late colonial era, when a number of indigenous people voluntarily participated in the market economy, such as in the cultivation of export crops. This article examines the involvement of local farmers in West Java in tea cultivation for export. While this was mediated by their engagement with the colonial government and the European tea estates and infrastructure, the active willingness of local farmers to embrace market economy was also crucial for the emergence of local tea plantations in the region. Throughout the early 20th century until the end of the Dutch colonial era local tea production tended to continuously increase. In addition, several tea enterprises belonging to indigenous people emerged in the region and at least one of them had considerably expanded by the end of the period. This study shows that the indigenous people were actually willing and able to actively participate in the market economy when they had the chance to do so.
\end{abstract}

Keywords and phrases: indigenous commercial activities, market economy, tea cooperatives, tea plantation, West Java

\section{Introduction}

In the colonial times, commerce in Java was mainly in the hands of the Europeans, while local people were marginalised from international and regional trade. The Dutch controlled the production and supply of export crops through monopoly and later through forced cultivation, reducing the roles of the local people to agricultural labour and micro production, without direct access to the lucrative international 
markets. The Dutch government or European companies bought the crops from the people at fixed prices, not market prices and channelled most of the profits to the European purses, while the local people lived on subsistence wages. Increasing calls for reform led to the colonial government acknowledging the detrimental impact of its policy on the local people and it admitted its responsibility to foster their economic development, reflected in the introduction of the Ethical Policy in the beginning of the 20th century, which moderately improved indigenous welfare, but without changing the fundamental structure and exclusivity of the colonial economy.

The development of economy in the Netherlands East Indies resulted in the existence of different economic system in the society. Boeke (1953) described it as a dual economy, while Furnivall (1944, 446-469) called it a plural economy. It was a society with two or more elements with different economic systems and characteristics, which can be characterised economically in terms of capitalist (Dutch) and pre-capitalist (local), or ethnically, in terms of the Europeans, Chinese and indigenous people. The term "indigenous" here refers to the local ethnic Sundanese, Javanese and other local population in Java. The indigenous populations were essentially considered backward and lacking in economic motives by Dutch colonial officials and scholars and their opinions varied on whether the indigenous situation should be seen as something inherent within the local society, or something shaped and iterated by historical circumstances and colonial policy and whether this was triggered by a rigid and vulnerable character among indigenous people who therefore needed protection, or whether they could be changed and developed.

These two viewpoints in evaluating the purported characteristics of the local people engendered inconsistency in the colonial policy, especially in the first half of the 20th century. On the one hand, the government wanted to promote indigenous welfare; on the other, it doubted their ability to progress, a view reinforced by the entrenched interests of the colonial (mainly Dutch) commercial elite. The government took steps to protect the local people from the worst excesses of colonial capitalism, which is considered harmful to their traditional values. Nevertheless, it is difficult to fully ascertain whether by protecting the local people from capitalism the government did not in fact tried to protect its own interests, ultimately at the expense of these people, in order to perpetuate colonial domination. On the other hand, indigenous villages were actually interconnected with the capitalist economy, despite their subordinate position (Alexander and Alexander 1991, 379). 
The Ethical Policy was a limited and arguably half-hearted policy of the colonial government aiming to promote the socio-economic development of indigenous people (Benda 1972, 207) and Adrian Vickers $(2006,18)$ describes it as an expression of white men's sympathy for the local people but without letting it "touch their pocket". In other words, the policy proclaimed appropriate platitudes about benefitting the colonised society, but the underlying principle remained colonisation and profit for the European capitalists. Nevertheless, it materially helped in increasing the welfare and commercial involvement of local people, which subsequently enabled them to buy European imported products, making the Indies a Dutch consumer market in addition to a source of raw materials, further boosting the colonial economy.

Indigenous welfare in this period was somewhat improved. The people became more involved in the production of export crops and were able to establish cooperative enterprises and reach an awareness and eagerness to obtain a more reasonable share of the market economy. Such development could be observed among others in the existence of indigenous tea plantations in West Java, the particular case discussed in this article.

\section{Indigenous Tea Cultivation in West Java}

Tea from West Java already comprised a major import in European markets by the second quarter of the 19th century (Spillane 1992, 33; Zakaria 2010,134). Tea cultivation was initially established directly by the colonial government, but after 1866 it was handed over to private enterprises and indigenous planters (Spillane 1992, 33-34). Initially the government and private estates grew Chinese tea, but by the end of the 19th century, specifically since 1878, the seed from China was replaced by Assam tea (from India), which produced better crops and whose demand in the European markets had significantly increased (Bernard 1924, 10; Department of Agriculture, Industry and Commerce [DAIC] 1930, 179; Setiawati and Nasikun 1991, 19). At about the same time, technique for manufacturing tea leaves was upgraded. Indigenous tea plantations also emerged in the last quarter of the 19th century (Spillane 1992, 34).

During this period of study, the Netherlands East Indies was among the major tea producers in the world, outshone only by British India and Ceylon (Division of Commerce of the Department of Agriculture, Industry and Commerce [DC-DAIC] 1930, 248; Departement van Economische Zaken [DEZ] 1939, 27; Kartodirdjo and Suryo 1991, 118). West Java had the biggest share of tea production in the Netherlands East Indies (DEZ 1938, 152) and the Sukabumi and Cianjur regencies 
contained the most important tea plantations (Departement van Landbouw in Nederlandsch-Indie [DLNI] 1910, 11).

Tea production in the Netherlands East Indies generally increased throughout the first half of the 20th century. The number of tea estates in Java grew from 200 in 1910 (Spillane 1992, 35) to 295 in 1920 (DAIC 1920, 111) and to 337 by 1938 (DEZ 1939, 146). The net area of tea plantations expanded from 89,384 hectares in 1920 (DAIC 1920, 111) to 213,000 hectares in 1940 (Spillane 1992, 35). Production increased from 8,000 tons in 1900 (Spillane 1992, 35) to 81,000 tons in 1938 (DEZ 1939, 154). The value of exports also generally increased from $f 7.1$ million in 1905 (DAIC 1916, 171) to f56.2 million in 1938 (Indisch Verslag 1939 1940,62 ), though the highest value of exports was $f 98$ million in 1928 (DAIC 1930, 329) (as shown in Table 1).

Table 1. Tea estates and production in Java

\begin{tabular}{ccccc}
\hline Year & $\begin{array}{c}\text { Total number of } \\
\text { tea estates }\end{array}$ & Area (in hectares) & $\begin{array}{c}\text { Total export } \\
\text { (in tons) }\end{array}$ & $\begin{array}{c}\text { Value of export } \\
\text { (in million guilders) }\end{array}$ \\
\hline 1900 & - & - & 8,000 & - \\
1905 & - & - & - & 7.1 \\
1910 & 200 & - & 15,000 & 11.5 \\
1920 & 295 & 89,384 & 46,000 & - \\
1928 & - & - & 70,000 & 98.0 \\
1930 & 323 & 168,198 & - & - \\
1938 & 337 & 205,485 & 81,000 & 56.2 \\
1940 & - & 213,000 & - & - \\
\hline
\end{tabular}

Sources: DAIC (1916; 1920; 1930), DEZ (1939), DLNH (1933), Indisch Verslag 1939 (1940) and Spillane (1992)

Despite the general growth in tea production and exports, there were fluctuations in particular years, related to international geopolitical developments and general commodity market trends. For instance, a tea surplus in 1920 caused a collapse of sales in 1921 (Departement van Landbouw, Nijverheid en Handel [DLNH] 1922, 90-91). This created obviously difficulties in Java and Sumatera, as a significant quantity of tea was rejected by the market (Bluett 1922, 19). That year, the indigenous tea production in Priangan, West Java, was described as bad and disappointing and many farmers reverted their tea plantations back to rice cultivation. For this reason, L. de Steurs, the Resident of Priangan, discouraged the expansion of local tea plantations (Arsip Nasional Republik Indonesia [ANRI] 1976, 84). However, after the annus horribilis of 1921, tea sales and production rebounded again (DC-DAIC 1926, 166). The next major threat was the global Great 
Depression started from 1929, which had more profound and long-lasting impacts on Dutch colonial production in general, including indigenous tea plantations. At first, world tea producers dealt with this problem by reducing production by $10 \%$ (DC-DAIC 1930, 247), but to no avail, thus they subsequently agreed to further systematic restriction of tea production from 1933 (Bluett 1933, 111). This shored up tea prices in world markets (Spillane 1992, 40), but local tea planters were the most affected by this policy, as discussed later.

The existence of the tea industry in West Java had attracted local people's involvement. A large number of local people worked in the surrounding tea plantations or factories, usually owned by European or Chinese planters (Thung 2007), or grew tea in their own smallholdings and sold the leaves to the estates, for processing and export. There were some indications that the tea industry had helped to improve indigenous economy in the surrounding areas and attracted people from other regions to come and seek their fortunes. Indigenous people engaged in the tea industry were able to elevate their standard of living, tiling their traditional earthen floors and buying chairs, tables and lamps and increasingly furnishing their houses according to European styles (DLNI 1910, 32-33; Van Doorn and Hendrix 1983, 14).

Various categories of indigenous people worked in tea estates, but most factory processes involved males engaged in tea factories as basket makers, transporters, carpenters, plasterers, welders and blacksmiths, besides getting involved in the early process of tea cultivation. Women were widely involved in agriculture, plucking, picking and processing the tea leaves. In the early 20th century, the salary of local tea workers in Sukabumi, West Java, for example, was 20-25 cents on average, while some received as much as 40 cents per day. The best position to be achieved by indigenous people was a head foreman, with a salary of $f 50$ to $f 60$ per month. During and after the World War I, the reduction of human resources from Europe opened chances for local people with a good education to achieve higher positions, including estate managers, but European owners usually did not trust them in financial matters (Lubis et al. 2003, 100-105). Since most of the tea workers were indigenous, local customs were sometimes embedded in plantation operations, such as slametan or prayer for safety included in the launching ceremony of estates (Soerabaijasch Handelsblad 1930).

The indigenous people acquired advantages not only by working in tea plantations but also by cultivating tea in their lands. Indigenous tea cultivation started in 1875 when the owners of Sinagar and Parakan Salak, two European tea estates, decided to provide some of the local people with seeds so they could grow tea in their own yards. The estates gave the seeds for free and the people grew them voluntarily, 
not through compulsory cultivation (Setiawati and Nasikun 1991, 11). The estates at the beginning distributed the seed without any stipulations, but later, prompted by competition, they required the seed receivers to sell their tea leaves exclusively to them. Attractive tea prices and initial profit obtained by indigenous planters had motivated more and more people to grow tea in their yards and lands (DLNI 1910, 11). The local planters sold their tea leaves to the tea estates belonging to Europeans and Chinese for further processing and sale to international markets. The transaction was basically beneficial for indigenous planters and the European and the Chinese estates (Vroon 1928, 1).

Indigenous tea plantation was then known as kampong (village) tea cultivation (kampong theecultuur) (Lekkerkerker 1924, 1). In the first few years, the people grew tea plants intermingling with food crops, but later they cultivated tea separately and gradually followed the estate's method of planting. The quality of kampong tea, however, was generally lower than that produced in the professional estates. Indigenous planters sold their wet leaves to the adjacent tea factories, for they were not able to produce premium quality dry tea leaves. Nevertheless, more than $20 \%$ of tea production in the Netherlands East Indies was sourced from the kampong tea plantations by 1930 (DAIC 1930, 179), although this percentage decreased to $15 \%$ or $16 \%$ subsequently (as shown in Table 2 ). Almost all of the indigenous tea production in the Netherlands East Indies came from West Java. It is interesting to note that the phenomenon of the emergence and development of indigenous tea plantations was not paralleled in British India, whose tea production was higher than that of the Netherlands East Indies, where cultivation was monopolised by large estates, at least up to 1930 (DC-DAIC 1930, 248).

Throughout the period of study, the area of indigenous tea plantation was greatly expanded, showing people's enthusiasm in the cultivation of lucrative export crops. In 1893 there were only 300 hectares of local tea plantation, but by 1909 this had developed into about 8,000 hectares, then to 11,000 hectares in 1910 and to 20,000 hectares in 1920, while by 1940 it swelled to 75,000 hectares (Spillane 1992, 45-46; compare with Purwanto 2002, 7). However, the value of tea exports declined after 1930 and the mid-1920s was probably the best time for local tea planters. In 1924, for example, indigenous planters produced 12,000 tons of tea leaves, an eight-fold increase compared to the production three years before. The estimated value was almost $f 10$ million, which was a great amount of money to be circulated in the village economies (Departement van Landbouw, Nijverheid en Handel, Afdeling Landbouw [DLNH-AL] 1925, 8). 
Table 2. Planted area and production of estates and indigenous tea in the Netherlands East Indies

\begin{tabular}{|c|c|c|c|c|c|c|c|}
\hline \multirow{3}{*}{ Year } & \multicolumn{2}{|c|}{$\begin{array}{l}\text { Planted area } \\
\text { (in hectares) }\end{array}$} & \multicolumn{4}{|c|}{$\begin{array}{c}\text { Production of dry tea } \\
\text { (in metric tons }-1,000 \text { kilogrammes) }\end{array}$} & \multirow{3}{*}{ Total } \\
\hline & \multirow[t]{2}{*}{ Estates } & \multirow[t]{2}{*}{ Indigenous } & \multicolumn{2}{|c|}{$\begin{array}{l}\text { Estates production } \\
\text { and wet leaf } \\
\text { purchased from } \\
\text { small estates }\end{array}$} & \multicolumn{2}{|c|}{$\begin{array}{l}\text { Indigenous } \\
\text { production } \\
\text { purchased by } \\
\text { estates }\end{array}$} & \\
\hline & & & & $\%$ & & $\%$ & \\
\hline 1925 & 98.000 & 29.000 & 41.515 & 78.8 & 11.167 & 21.2 & 52.682 \\
\hline 1926 & - & - & 48.304 & 76.8 & 14.616 & 23.2 & 62.920 \\
\hline 1927 & - & - & 52.387 & 80.5 & 12.691 & 19.5 & 65.078 \\
\hline 1928 & 115.237 & 34.844 & 57.254 & 78.6 & 15.608 & 21.4 & 72.862 \\
\hline 1929 & 120.442 & 37.010 & 59.825 & 79.2 & 15.758 & 20.8 & 75.583 \\
\hline 1930 & 126.996 & 41.202 & 57.628 & 80.0 & 14.363 & 20.0 & 71.991 \\
\hline 1931 & 131.440 & 41.801 & 66.406 & 81.7 & 14.903 & 18.3 & 81.309 \\
\hline 1932 & 135.704 & 41.390 & 69.513 & 84.8 & 12.424 & 15.2 & 81.937 \\
\hline 1933 & 137.844 & 46.498 & 63.494 & 84.3 & 11.798 & 15.7 & 75.292 \\
\hline 1934 & 138.018 & - & 59.534 & 83.5 & 11.759 & 16.5 & 71.293 \\
\hline 1935 & 138.231 & 60.000 & 58.793 & 82.3 & 12.622 & 17.7 & 71.415 \\
\hline 1936 & 138.750 & $66.243^{*}$ & 62.952 & 83.3 & 12.629 & 16.7 & 75.581 \\
\hline 1937 & 139.034 & $67.501^{*}$ & 62.346 & 83.7 & 12.170 & 16.3 & 74.516 \\
\hline 1938 & 138.319 & $67.166^{*}$ & 68.332 & 84.0 & 12.997 & 16.0 & 81.329 \\
\hline 1940 & 138.000 & 75.000 & - & - & - & - & - \\
\hline
\end{tabular}

Sources: Compiled from DAIC (1930), DLNH (1933), DEZ (1934; 1937; 1938; 1939) and Spillane (1992). Note: Indigenous planted area in 1936 to $1938\left(^{*}\right)$ are preliminary figures.

The development of indigenous tea plantation was supported by the colonial government, which provided free seeds for local planters and also financial assistance (DLNH-AL 1925, 5). Between 1905 and 1910, the government's district banks in Sukabumi, West Java, provided financial support of no less than $f 61,000$ for indigenous tea planters in the regency (DLNI 1910, 15). Besides government help, the response of the local people in this respect was very crucial to ensure the development of kampong tea and the enhancement of their economy. In some measure, the people in West Java had shown their aptitude in seizing the immediate opportunity offered to develop their economic prospects, which suggests a characterisation of West Javanese people as more open and responsive to the market economy and more amenable to the penetration of money in their community, contrary to the people of Central and East Java, who were considered 
to be more inward-looking and less receptive to commercialisation (Fryer and Jackson 1977, 118).

The participation of the local tea planters in West Java is quite similar to the local rubber planters in the Outer Islands (Dutch colonial possessions in Southeast Asia other than Java and Madura), especially in Sumatra and Borneo. Rubber was introduced somewhat later by the colonial government, in 1900 (Furnivall 1944, 318). This product was soon booming due to high demand from industrialised countries, especially from the United States. Rubber demand and prices peaked in the mid-1920s and rubber contributed to one third of the total value of the Netherlands East Indies export commodities. Local planters in Sumatra and Borneo participated actively in developing rubber plantations. The colonial government also encouraged indigenous planters to participate in developing this produce. However, unlike in Java, indigenous planters in Sumatra and Borneo had more direct access to international markets and were more active in utilising this access. Closer access to Singapore allowed the products of these local planters to flow directly to the international markets in that city, through the intermediation of indigenous pilgrims (hajis) and Chinese middlemen (Lindblad 2002, 126-127).

Involvement in rubber production contributed significantly to the economic improvement of the indigenous societies in rubber-producing areas such as Palembang, Lampung and Jambi in South Sumatra and Banjarmasin in Borneo. Many homes were thus able to purchase luxury goods such as radios, gramophones and motorised vehicles. Similarly, public facilities such as roads and bridges were developed. The local people were quite aware of the international market trends and were eager to discuss them (Hart 1942, 93). The rubber industry also experienced a depression in the 1930s which was later overcome by restriction by the colonial government through the implementation of export duties for rubber. Although the application was not fully successful at first, by 1936 the restriction system had been widely accepted, including by the indigenous people (Furnivall 1944, 438). Meanwhile, tea restriction was felt to be more difficult and unfair for the tea planters in West Java, as discussed later in this article.

\section{The Emergence of Indigenous Tea Cooperatives}

Most local planters grew tea individually on their smallholdings and they lacked sufficient capital to open tea estates on par with the European and Chinese planters. A lack of capital was one of the main challenges faced by local entrepreneurs at the time. The colonial government through its Ethical Policy had opened banks up to the village level to make it easier for the indigenous people to borrow money, but they were still unfamiliar with the administrative procedure involved in 
borrowing money from bank. It was easier for many people to borrow from private money-lenders, but with higher risk and the purpose of borrowing was usually for consumptive reasons rather than for opening or developing a business (Van Zanden 2009, 174-175; Van der Kroef 1994, 277).

The other challenge was their ability to start and to maintain a commercial activity. Local people were rarely from families with business experience that could readily be followed or taken as example, therefore they depended on guidance and support from officials, at least in the first years of their business activities, to ensure that their business operations were on the right track. Registering and managing a business organisation was also challenging for the indigenous people. They could not formally register their business with the Dutch statutory authorities, since they were not accustomed with the Dutch language and law and also not ready for the Dutch type of business organisation that was usually put under the title of Naamloze Venootschap (NV). By 1915, the Dutch law introduced the cooperative system, but it was still registered with the Dutch language. Nevertheless, the cooperative system was subsequently used by the indigenous entrepreneurs to start businesses, though they were still not registered formally. Later in 1927, the colonial government issued new cooperative regulation specifically for the indigenous people that allowed local people to register their businesses with a relatively easy process and low cost (Boeke 1928, 11-13).

During this period, tea estates were mostly owned by Europeans. Some of these companies had large capital and big plantations, sometimes coupled with different types of plantations such as quinine and rubber. The previously mentioned ParakanSalak tea estate was actually the first tea company in Java that operated in the vicinity of Salak Mountain in Priangan, West Java (De Coul 1912, 10). However, this company and also Sinagar, were not included in the list of the Dutch tea estates in De Coul's survey published in 1912. Other companies that appeared in this 55-page book included Algemeene Nederlandsch-Indische Thee-Cultuur Maatschappij, Amsterdam Thee-Cultuur-Maatschappij, Assam-Thee Onderneming "BodjongTerong", Landbouw Maatschappij Preanger Regentschappen and West-Java Thee Cultuur Maatschappij, almost all of them were headquartered in Amsterdam, with capital of $f 300,000$ or more and had extensive plantations in West Java region.

Landbouw Maatschappij Preanger Regentschappen, for example, had capital of $f 2$ million. In 1911, yields from its plantations in the Tjikorai region were around 543,000 half kilogrammes of dried tea leaves and from the Patoeha region, around 516,000 half kilogrammes of wet tea leaves. The company's profit for that year was more than $f 100,000$ and $5.75 \%$ of this profit was distributed as dividends to the shareholders (De Coul 1912, 42-43). West-Java Thee Cultuur Maatschappij 
had a capital of $f 1.5$ million. In 1911, the company produced around 300,000 half kilogrammes of dried tea leaves, as well as other agricultural products. The company's profit for that year was more than $f 54,000$ (De Coul 1912, 51-52). The above two companies are examples of large and growing Dutch tea companies, at a time when the indigenous tea planters still worked individually or with family and did not even have small companies.

However, in the beginning of the 20th century, some tea planters in Sukabumi, through the support of Government's officials, founded cooperative associations. These tea cooperatives could in no way match the capital and other resources of the largest tea estates, but they were comparable with smaller and middling ones. They organised the underwriting of associations and later legal arrangements, operating a good sum of capital and generating generous income. The first two associations were founded in Sukabumi in 1911-or 1915 according to Vroon $(1928,21)$ —with the name of Madoe Tawon (literally means "honey bee") and

Mitra noe Tani ("partner of farmers") (Lekkerkerker 1924, 2). Other similar associations were founded, but they were less well-known. Of these two, it was only Madoe Tawon that existed up to the end of the colonial period. Mitra noe Tani's tea production was still reported in 1926 (Bataviaasch Nieuwsblad 1926), but an article in 1939 affirms that Mitra noe Tani had ceased to exist several years before (Hamid 1939a; Penoentoen Kemadjoean 1939).

Mitra noe Tani and Madoe Tawon started in the same year with nearly the same capital, collected gradually from their members. Both associations were legally registered in 1918. Lands for tea plantations were provided by the government and Madoe Tawon managed nearly $35 \mathrm{bau}$ of land, while Mitra noe Tani commanded about 20 bau (Lekkerkerker 1924, 3-5), equal to about 24.5 hectares and 14 hectares respectively. Despite their comparable commencement, Madoe Tawon turned out to be more successful in the following years, partially because of a lucrative deal with a European company. In 1918, it made a written contract with a European company, N. V. Cultuurmaatschappij Sinagar, located in Sukabumi, to directly sell its wet leaves to Sinagar on a regular basis (DLNH-AL 1925, 11). By this device, Madoe Tawon secured sales of its production and received relatively better payment from the estate, while Sinagar also ensured a fixed supply of wet tea leaves from this cooperative. The contract was made for one year and would be automatically extended, provided no party disappointed and withdrew from the contract (Lekkerkerker 1924, 8; Bataviaasch Nieuwsblad 1927). Indigenous planters and cooperatives usually sold their tea leaves to the estates indirectly through middlemen, commonly Chinese, thus reducing their profits. 
Madoe Tawon had borrowed money from a district bank in Sukabumi for its operation. The profit from the tea plantation was good so it had no problem to pay the debt. The initial profits were reinvested to expand the plantation and after a few years the shareholders received favourable dividends (Lekkerkerker 1924, 6-7). Madoe Tawon started its business with a total capital of $f 5,000$, consisted of $f 3,000$ cash and a land worth of $f 2,000$. In 1923, the total value of its possessions was $f 20,570$, a fourfold increase on its original capital. The total dividend received by its members that year was even greater than its possession, namely $f 25,887.82$ (Lekkerkerker 1924, 8-9; De Indische Courant 15 July 1924), which signified that in that year only the initial investment was already paid off. From 1915 to the mid-1930s, members of Madoe Tawon actually received an overall dividend of $f 105,000$. Thus, the average annual dividend obtained by the members of Madoe Tawon was $f 5,000$. This was $170 \%$ of the initial capital, namely $f 3,000$, invested by the members in the first years (Hamid 1939a). The benefit was indeed enormous, but it also showed that the early arrangement to utilise the profit mostly for business expansion was short-lived and the members wanted to quickly enjoy the revenues, which was obviously detrimental to long-run economic sustainability and the business stopped growing. Madoe Tawon did not have a reserve fund for tax and was unprepared when in the beginning of the 1930s the government introduced an enterprise tax from 1928 to 1932 to be paid by the cooperative. The pressure was doubled by the Great Depression of the 1930s, which severely hit the tea industry, as discussed previously. Madoe Tawon almost collapsed at that juncture (Hamid 1939a). It is probable that Mitra noe Tani was also severely smashed by the depression in the early 1930s and failed to continue the business.

However, Madoe Tawon managed to recover from these difficulties and in 1934 it rose again under new management, led by Raden Soedarma Soeradiradja as the chairman of the cooperative (Hamid 1939b). He had previously worked as an agricultural consultant in the government office and had experience in assisting some European tea estates. In the early 1930s, Soeradiradja resigned from public office and decided to help managing several indigenous establishments, including a bank and a rubber factory (ANRI 1943). Besides Soeradiradja, Madoe Tawon's leadership was also filled by other capable persons such as Sawilan Martolojo, who at the end of the colonial period held a position of administrator of the cooperative (Hamid 1939c).

Madoe Tawon subsequently negotiated its problems with the enterprise tax, halting dividend payments for a while and re-directing profits back to business expansion. Consequently, by 1939 its business was not only expanded but also diversified. It possessed $50 \mathrm{bau}$ of tea plantation, 100 hectares of citronella plantation and it planned to open a rubber plantation (Hamid 1939b). It also proposed to open 
a tea factory with a budget of $f 8,000$ (Asia Baroe 1939a; Hamid 1939c) and the first stone for the foundation of this factory was laid at the end of that year (Asia Baroe 1939b). A school of 50 students opened up in Sawilan's house in Nagrak village, Sukabumi, in 1937, which in modern terms might be considered an aspect of corporate social responsibility by the cooperative (Berita Priangan 1937). Madoe Tawon's performance in the tea industry cannot be considered mediocre and the quality of its tea production was in fact acknowledged as equal to that of the European estates (Bataviaasch Nieuwsblad 1941; De Indische Courant 1941). Madoe Tawon thus demonstrated indigenous capacity in dealing with modern industrial entrepreneurship.

\section{Indigenous Planters and the Market Economy}

Indigenous activities in several industries, including tea plantations, do not bear out the characterisation of some Dutch officials and scholars as fatalist and unappreciative of material development (Helwig and Tagliacozzo 2009, 260-261), a lack of enterprising capacity (Locher-Scholten 1986, 204) and being lazy and quickly satisfied (Hasselman 1977, 86), less motivated by economic incentive (Van der Kroef 1994, 259), or generally being driven by communal, non-economic motives, being alien to trading and the market economy and unable to give up the pre-capitalistic village economy (Boeke 1942, 17-23). Such characteristics would fail to explain indigenous participation in tea plantation in West Java and their important contribution in the industry. Despites their weaknesses, there are a lot of examples to point out that in many occasions the indigenous people actually behaved in accordance with market logic and did not overlook economic incentives and opportunities.

It is true that the people entered the industry through government encouragement and assistance, but this was restricted in the initial phase. Madoe Tawon and Mitra noe Tani, for example, already operated independently by 1918 and the government found that they needed no further assistance (Lekkerkerker 1924, 10). Local plantations that produced kampong tea had largely expanded without any coercion from the government, rather they were stimulated by profitable tea sales in the market. They took part in and withdrew from tea cultivation driven by economic considerations. When the price of tea leaves was high, a lot of local planters in Sukabumi converted their lands into tea plantation, but when the price of tea fell significantly in 1920 many of them abandoned tea and re-planted their lands with more lucrative food crops (ANRI 1976, LVI). A report also related how local farmers actually behaved according to a reasonable economic response. During the drop of tea prices in 1920, indigenous tea planters avoided plucking their tea leaves because obviously they could not compete with the estates whose 
leaves were of higher quality. However, when the price rose considerably in 1923 , they plucked their tea leaves excessively, because the demand at that time was very high and the buyers tended to discount the quality standard (DLNH-AL 1925, 6-7), which in normal circumstances was strictly overseen (De Indische Courant 1928).

Indigenous planters usually sold their tea leaves to middlemen who subsequently sold them to the estates. They could not sell directly to the international markets, since they did not have access and capital for that. However, the leading members of these planters were at least aware that tea price was shaped by the market's supply and demand, as manifest during the 1930s economic depression and the enactment of tea restriction by the main countries of tea producers, namely the Netherlands East Indies, India and Ceylon. To halt the decline of world tea prices, the major tea producers came to an agreement in 1933 to restrict tea production for five years, to be extended further if needed (Spillane 1992, 40).

Tea restriction helped to stabilise tea prices and therefore saved the industry, but local planters felt that the implementation was detrimental to them and consequently they voiced their concern. A critic under the alias Patjar Merah (Red Henna) for example wrote in the Djawa Barat newspaper that the intention of tea restriction policy by the government was noble, but the execution was bad and seriously troubled local planters. He also considered the government was insensitive to the real situation faced by the people (Merah 1933a; 1933b; 1933c).

The policy regulated annual quotas of production to be sold in the market, calculated based on the tea production from 1929 to 1932 and 2/11 of this quota was to be purchased by the estates from the indigenous planters (Djawa Barat 1933a). To control the quota, the government distributed licenses for tea factories to obtain a certain amount of tea leaves in accordance with their regular capacity of production. They had to use some of their quotas to buy kampong tea leaves. However, there was not a single license given to indigenous planters or cooperatives, which undermined their fledgling position in the industry. They had no bargaining power in the presence of license holders and middlemen (Karim 1933a). Even a leading indigenous enterprise such as Madoe Tawon still struggled to the end of the colonial period to be regarded equal to European estates and to be entitled to possess a license (Hamid 1939b).

This situation prompted local planters to establish a union, namely Comite Penoeloeng Pertanian Teh (Aid Committee for Tea Cultivation) so they could express their distress. Karim, the secretary of the union, voiced criticism several times in Djawa Barat (Karim 1933b). He warned the government against possible 
irregularities committed by license holders. They might covertly disregard their obligation to purchase some tea leaves from the local people and substituted them with their own products (Karim 1933c), or they might trade some of their quotas to other parties (Karim 1933d). Indigenous tea planters perceived that they were receiving unfair dealing under this policy. In the beginning of the 1930s, the price of kampong wet tea leaves dropped to four to five cents per kilogrammes, only half of the lowest price when over-supply of tea happened in 1920 to 1921 . The price of tea leaves actually started to rise again several months after the introduction of tea restriction, but according to Karim it remained stagnant for kampong tea (Karim 1933d; Djawa Barat 1933b). Indigenous planters thus continued to suffer when others began to breathe again. Thus, the policy was described in an article as "theory bagoes, praktijk sedih. Sangat menyedihkan terhadap kaoem lemah" (good theory, miserable execution. Very depressing for the weak) (Karim 1933e). Tea restriction also affected the medium and larger European estates, but they did not noticeably complain about the government regulations regarding tea restriction and license distribution, probably because most of them received licensure. However, protests came from small European tea estates and also from the native tea planters, who felt that the introduction of tea quota and the distribution of tea licenses were unfair to them (Karim 1933a). However, they voiced their criticism separately and we are focusing only with the complaint of the native tea planters in this article.

Karim revealed the situation confronted by the local tea planters and expressed their protest to the government. He called for the application of international market price of tea to determine a minimum price of kampong tea. Basically, the price should be formed independently by the market without government's intervention. The suppliers, as well as the buyers, would compete among themselves to offer the best product and the best price. According to Karim, this was not the case under the restriction policy, since the estates that possessed licenses had the upper-hand to decide (or even manipulate) the price, while the smaller estates and producers had little with which to bargain (Karim 1933f). Wet kampong tea leaves at that time were bought at around two and a half cents per half kilogrammes or five cents per kilogrammes, which was disproportionately low relative to tea prices in international markets (Karim 1933g). Therefore, the Comite's articles in Djawa Barat again and again demanded a minimum price for kampong tea. The articles asked the officials, "Mana minimum prijzen" (where is the minimum price) (Karim 1933h). They also underlined that the minimum price would fluctuate corresponding to international market price (J. A. K. 1933). The articles, however, did not give any information regarding how much the international tea price actually was, nor give any suggestion how much the ideal price for kampong tea leaves should be. 
Nevertheless, this showed people's awareness about the market and their active demand for a slice of it.

On the whole, indigenous tea planters in West Java did not hesitate to grasp any commercial opportunity and they actually displayed noticeable progress during this period of study. Nevertheless, this does not mean they received equal treatment like the Europeans and the Chinese. The tea restriction policy had shown, as observed by the local planters, that the government was reluctant to give license and to establish a minimum kampong tea price based on international market prices on behalf of indigenous people. The government might have its own rationale to deny popular demand, but the people seemed to regard the regulations as being made primarily to secure the interests of European trade and industry and the indigenous producers were the last party allowed to benefit from colonial economic policy.

\section{Conclusion}

The Dutch colonial government's new Ethical Policy from the beginning of the 20th century aimed to increase the welfare of the indigenous society that had generally suffered economically under the previous regime. The good intention of the government through this new policy was not always followed by a consistent implementation, in accordance with what was promised. This policy in general did not change the position of the indigenous peoples, who remained in the lowest stratum of the colonial economy, but it did materially improve the socioeconomic conditions of many of them and opened up new opportunities for voluntarily engagement in profitable plantations and industries. The local people in West Java made good use of this opportunity, including through tea plantations.

The indigenous people in West Java since the end of the 19th century had participated in the tea industry, not only as workers in plantations and factories, but also as partners to the European tea estates by cultivating tea on their own lands and selling tea leaves to the estates. These indigenous tea planters gained support from the estates and from the government in term of distribution of free seeds and loans from local banks. However, their participation was driven by market appeal and not by coercion by the colonial government. Indigenous planters seized this opportunity and later had an important share in tea production. Several local tea cooperatives had emerged since the second decade of the 20th century and at least one of them had survived to the end of Dutch colonial period. Local tea cooperatives actually expanded and showed that they had the capability to develop business independently and to compete with the other enterprises without having to always be supported by the colonial government. 
Despite some shortcomings, the activities of indigenous tea planters generally contradict the negative conceptualisation of indigenous people by some colonial public servants. They readily responded to economic incentives, reacted reasonably to economic challenges and demanded proper reference from the market during economic crisis and restriction. They even formed associations to defend their interests in the tea business and actively voiced their criticism of the government's restriction policy, which they felt to be unfair to them during these difficult times. Indigenous tea planters in this period had passed the era of forced cultivation and subsistence living, partaking in the tea industry and becoming more ready and able to embrace and contribute to the market economy.

\section{Bibliography}

Alexander, J. and Alexander, P. 1991. Protecting peasants from capitalism: The subordination of Javanese traders by the colonial state. Comparative Studies in Society and History 33(2): 370-394. https://doi.org/10.1017/S0010417500017060

Arsip Nasional Republik Indonesia (ANRI). 1976. Memori serah jabatan 1921-1930 (Jawa Barat). Jakarta: ANRI.

. 1943. "Raden Soedarma Soeradiradja". Orang Indonesia yang terkemuka di Djawa, No. 2972. Unpublished archive material.

Asia Baroe. 1939a. Madoe Tawon, 23 August.

—. 1939b. Madoe Tawon, 6 December.

Bataviaasch Nieuwsblad. 1941. Huidige omvang, 22 July. Retrieved from http://www. delpher.nl/nl/kranten/view?query=Madoe + Tawon\&coll=ddd\&identifier $=$ ddd $\%$ 3A011221912\%3Ampeg21\%3Aa0159\&resultsidentifier=ddd\%3A011221912\% 3Ampeg21\%3Aa0159 (accessed 23 February 2019).

. 1927. Inlandsche landbouworganisaties, 26 April. Retrieved from https:// www.delpher.nl/nl/kranten/view?query=Inlandsche+Landbouworganisaties $\&$ coll=ddd\&page $=1 \&$ facets[periode][] $=2 \mid 20$ e_eeuw $|1920-1929| 1927 \mid \&$ identifier $=\mathrm{d}$ dd\%3A011039383\%3Ampeg21\%3Aa0205\&resultsidentifier=ddd\%3A011039383 \%3Ampeg21\%3Aa0205 (accessed 23 February 2019).

—. 1926. De productiviteit der inlandsche theetuinen, 22 July. Retrieved from http://www.delpher.nl/nl/kranten/view?query= Madoe+Tawon\& coll=ddd\&identifier=ddd\%3A011036394\%3 Ampeg $21 \% 3$ Aa0015\&resultsidentifier=ddd\%3A011036394\%3Ampeg21\%3Aa0015 (accessed 23 February 2019).

Benda, H.J. 1972. Continuity and change in Southeast Asia. New Haven: Yale University Southeast Asian Studies.

Berita Priangan. 1937. Nagrak ngamoek?, 27 September.

Bernard, C. 1924. De geschiedenis van de theecultuur in Nederlandsch-Indie. In Gedenkboek der Nederlandsch indische theecultuur 1824-1924, 1-18. Weltevreden, Java: G. Kolff \& Co.

Bluett, H.A.N. 1933. Economic conditions in the Netherlands East Indies, February, 1933. London: His Majesty's Stationary Office. 
1922. Report on the economic situation of the Netherlands East Indies to March, 1922. London: His Majesty's Stationary Office.

Boeke, J.H. 1953. Economics and economic policy of dual societies, as exemplified by Indonesia. Haarlem: H. D. Tjeenk Willink \& Zoon.

. 1942. The structure of Netherlands Indian economy. New York: International Secretariat Institute of Pacific Relations.

- 1928. Alasan dan maksoed atoeran tentang Perkoempoelan Koperasi Boemipoetra (stbl. 1927 no. 91). 2nd Ed. Weltevreden, Java: Balai Poestaka.

De Coul, T.P.J.C.O. 1912. Nederlandsch-indische thee-ondernemingen en hunne waarde voor den belegger. Amsterdam: Van der Werff \& Hubrecht.

De Indische Courant. 1941. Van onderling-hulpbetoon, 3 April. Retrieved from http:// www.delpher.nl/nl/kranten/view?query $=$ madoe+tawon $\&$ coll $=$ ddd \&page $=1 \&$ facets[periode][] $=1 \mid 20 \mathrm{e}$ eeuw $|1940-1949| \&$ identifier $=$ ddd $\% 3 \mathrm{~A} 011176553 \% 3 \mathrm{Am}$ peg21\%3Aa0069 \& resultsidentifier=ddd\%3A011176553\%3 Ampeg21\%3Aa0069 (accessed 23 February 2019).

- 1928. Van de Preanger hoogvlakte, 16 October. Retrieved from http:// www.delpher.nl/nl/kranten/view?query=Van+de+Preangerhoogvlakte $\&$ coll $=$ ddd \&page $=4 \&$ identifier $=\mathrm{ddd} \% 3 \mathrm{~A} 010278703 \% 3 \mathrm{Ampeg} 21 \% 3 \mathrm{Aa} 0115$ \&resultsidentifier $=\mathrm{ddd} \% 3 \mathrm{~A} 010278703 \% 3 \mathrm{Ampeg} 21 \% 3 \mathrm{Aa} 0115 \quad$ (accessed 23 February 2019).

1924. De inlandsche landbouw op de jaarbeurste Bandoeng, 15 July. Retrieved from http://www.delpher.nl/nl/kranten/view?query=Madoe+ Tawon \& coll $=$ ddd \&identifier $=\mathrm{ddd} \% 3 \mathrm{~A} 010277538 \% 3 \mathrm{Ampeg} 21 \% 3 \mathrm{Aa} 0032 \&$ resultsidentifier $=\mathrm{ddd} \% 3 \mathrm{~A} 010277538 \% 3 \mathrm{Ampeg} 21 \% 3 \mathrm{Aa0032} \quad$ (accessed 23 February 2019).

Departement van Economische Zaken (DEZ). 1939. De landbouwexportgewassen van Nederlandsch-Indie in 1938 (Beplanteuitgestrektheden, producties en uitvoeren). Batavia: Landsdrukkerij.

1938. De landbouwexportgewassen van Nederlandsch-Indie in 1937 (Beplanteuitgestrektheden, producties en uitvoeren). Batavia: Landsdrukkerij.

- 1937. De landbouwexportgewassen van Nederlandsch-Indie in 1936 (Beplanteuitgestrektheden, producties en uitvoeren). Batavia: Landsdrukkerij.

- 1934. De landbouwexportgewassen van Nederlandsch-Indie in 1933 (Beplanteuitgestrektheden, producties en uitvoeren). 's Gravenhage: MartinusNijhoff.

Departement van Landbouw in Nederlandsch-Indie (DLNI). 1910. De theecultuur in de Preanger regenschappen: Inzonderheid die van de inlandschebevolking. Buitenzorg, Java: Drukkerij Departmen van Landbouw.

Departement van Landbouw, Nijverheid en Handel (DLNH). 1933. De landbouwexportgewassen van Nederlandsch-Indie in 1932 (Beplanteuitgestrektheden, producties en uitvoeren). 's Gravenhage: MartinusNijhoff.

. 1922. Report on commerce, industry and agriculture in the Netherlands East Indies during 1921. Buitenzorg, Java: Archipel-Drukkerij. 
Departement van Landbouw, Nijverheid en Handel, Afdeling Landbouw (DLNHAL). 1925. De theecultuur van de inlandsche bevolking. Weltevreden, Java: Landsdrukkerij.

Department of Agriculture, Industry and Commerce (DAIC). 1930. 1930 handbook of the Netherlands East-Indies. Buitenzorg, Java: DAIC.

. 1920. Yearbook of the Netherlands East Indies. Batavia: DAIC.

- 1916. Yearbook of the Netherlands East Indies. Batavia: DAIC.

Division of Commerce of the Department of Agriculture, Industry and Commerce

(DC-DAIC). 1930. Report on commerce in Netherland India for the year 1930.

Buitenzorg, Java: Government Printing Office.

. 1926. Report on commerce, industry and agriculture in the Netherlands EastIndies during 1925. Weltevreden, Java: Landsdrukkerij.

Djawa Barat. 1933a. Thee-restrictie: Standaard productie-patokan hasil, 2 October.

. 1933b. Thee restrictive, 10 November.

Fryer, D.W. and Jackson, J.C. 1977. Indonesia. London: Ernest Benn Limited.

Furnivall, J.S. 1944. Netherlands India: A study of plural economy. Cambridge: Cambridge University Press.

Hamid, A. 1939a. "Madoe Tawon", satoe coooperatie dari theeplanters bangsa Indonesia di daerah Soekaboemi, 1. Asia Baroe, 5 July.

- 1939b. "Madoe Tawon", satoe coooperatie dari theeplanters bangsa Indonesia di daerah Soekaboemi 2. Asia Baroe, 8 July.

_. 1939c. "Madoe Tawon", satoe coooperatie dari theeplanters bangsa Indonesia di daerah Soekaboemi (penoetoep). Asia Baroe, 12 July.

Hart, G.H.C. 1942. Recent development in the Netherlands-Indies. The Geographical Journal, 99(2): 81-102. https://doi.org/10.2307/1788121

Hasselman, C.J. 1977. General survey of the results of the investigation into economic prosperity in Java and Madura, held in 1904-5. In Indonesia: Selected documents on colonialism and nationalism, 1830-1942, ed. C.L.M. Penders. Brisbane: University of Queensland Press.

Helwig, T. and Tagliacozzo, E, eds. 2009. The Indonesia reader: History, culture, politics. Durham: Duke University Press. https://doi.org/10.1215/9780822392279

Heng, L.T. 2007. In the shadow of a volcano: The adventures of growing up in Java. Bangkok: SEAMEO Regional Center for Archeology and Fine Arts.

Indisch Verslag 1939. 1940. 's Gravenhage: Algemeene Landsdrukkerij.

Indisch Verslag 1934. 1935. 's Gravenhage: Algemeene Landsdrukkerij.

J.A.K. 1933. Theerestrictie. Djawa Barat, 18 November.

Karim, J.A. 1933a. Thee-restrictie terhadap peroesahaan thee boemipoetra dan pertanian ketjil. Djawa Barat, 29 August.

1933b. Thee-restrictie terhadap peroesahaan thee boemipoetra dan pertanian ketjil. Djawa Barat, 30 August.

. 1933c. Thee-restrictie. Djawa Barat, 23 September.

. 1933d. Thee-restrictie terhadap peroesahaan thee boemipoetra dan pertanian ketjil. Djawa Barat, 18 August.

1933e. Theerestrictie. Djawa Barat, 10 November.

. 1933f. Thee-restrictie (penoetoep). Djawa Barat, 26 September. 
-1933g. Theerestrictie. Djawa Barat, 11 November.

1933h. Theerestrictie. Djawa Barat, 25 October.

Kartodirdjo, S. and Suryo, D. 1991. Sejarah perkebunan di Indonesia: Kajian sosialekonomi. Yogyakarta: Penerbit Aditya Media.

Lekkerkerker, T.J. 1924. Twee inlandsche thee-planters-associaties in de preanger regenschappen. In Gedenkboek der Nederlandsch indische theecultuur 1824-1924, 59-69. Weltevreden, Java: G. Kolff \& Co.

Lindblad, J.T. 2002. The late colonial state and economic expansion, 1900-1930s. In The emergence of a national economy: An economic history of Indonesia, 1800-2000, eds. H. Dick, V.J.H. Houben, J.T. Lindblad and Thee K.W. Honolulu: Allen \& Unwin and University of Hawai'i Press.

Locher-Scholten, E.B. 1986. Some remarks on the role of women in indigenous agriculture in colonial Java (19th and 20th century). In Papers of the fourth Indonesian-Dutch history conference Yogyakarta 24-29 July 1983, vol. I, agrarian history, ed. S. Kartodirdjo. Yogyakarta: Gadjah Mada University Press.

Lubis, N.H. et al. 2003. Sejarah tatar Sunda, vol. 2. Bandung: Pusat Penelitian Kemasyarakatan dan Kebudayaan Lembaga Penelitian Universitas Padjadjaran and Masyarakat Sejarawan Indonesia Cabang Jawa Barat.

Merah, P. 1933a. Theerestrictie: Nasi soedah djadi boeboer!. Djawa Barat, 20 October.

- 1933b. Theerestrictie: Dalam praktijk. Djawa Barat, 27 October. 1933c. Theerestrictie: Dalam praktijk. Djawa Barat, 1 November.

Penoentoen Kemadjoean. 1939. "Madoe Tawon", cooperatie dari thee planters dengan koers 600 pct, 5 August.

Purwanto, B. 2002. Peasant economy and institutional change in late colonial Indonesia. Paper presented at International Conference on Economic Growth and Institutional Change in Indonesia in the 19th and 20th Centuries, Amsterdam, 25-26 February.

Setiawati, I. and Nasikun. 1991. Teh: Kajian sosial-ekonomi. Yogyakarta: Penerbit Aditya Media.

Soerabaijasch Handelsblad. 1930. Nieuwe thee-onderneming, 1 April. Retrieved from http://www.delpher.nl/nl/kranten/view?query=slamatan\&coll=ddd\&page= 4\&facets[periode][] $=2 \mid 20$ e_eeuw $|1930-1939| 1930 \mid \&$ identifier $=\mathrm{ddd} \% 3 \mathrm{~A} 01110880$ 5\%3Ampeg21\%3Aa0150\&resultsidentifier $=$ ddd $\% 3$ A011108805\%3Ampeg21\%3 Aa0150 (accessed 23 February 2019).

Spillane, J.J. 1992. Komoditi teh: Peranannya dalam perekonomian Indonesia. Jakarta: Kanisius.

Van der Kroef, J.M. 1994. Dutch colonial policy in Indonesia, 1900-1941. Phd diss., Columbia University.

Van Doorn, J. and Hendrix, W.J. 1983. The emergence of a dependent economy: Consequences of the opening up of West Priangan, Java, to the process of modernization. Rotterdam: CASP.

Van Zanden, J.L. 2009. Credit and the colonial state: The reform of capital markets on Java, 1900-30. In Credit and debt in Indonesia, 860-1930: From peonage to pawnshop, from kongsi to cooperative, eds. D. Henley and P. Boomgaard, 160177. Singapore: ISEAS Publishing. https://doi.org/10.1355/9789812308474-010 
Vickers, A. 2006. A history of modern Indonesia. Cambridge: Cambridge University Press.

Vroon, L.J. 1928. The bevolkings theecultuur in de residentie West-Priangan. Wageningen, Netherlands: H. Veenman \& Zonen.

Zakaria, M.M. 2010. Priangan abad ke-19 dalam arus dinamika sosial-ekonomi. PhD diss., Universitas Padjadjaran. 